\title{
Lithic technological strategies of the earliest herders at Lake Turkana, northern Kenya
}

Steven T. Goldstein

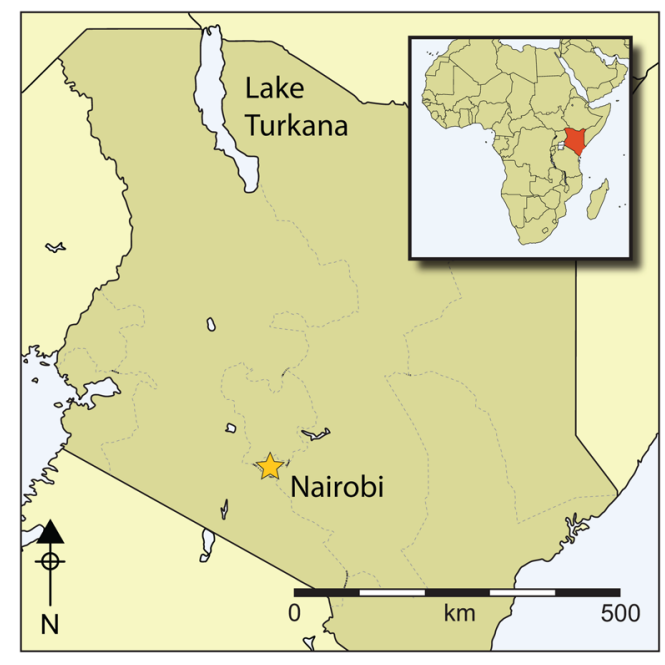

The spread and persistence of early forms of mobile food production throughout Africa depended on the ability of herding communities to adapt to novel social and environmental challenges. This article presents the first quantitative technological analysis of lithic assemblages from the earliest eastern African pastoralist sites, located in the Lake Turkana Basin of northern Kenya. In this region, transitions to pastoralism involved the adoption of a new, regionally homogeneous technological strategy, which emphasised utility and flexibility. This research provides new insights into how early herders were able to spread through sub-Saharan Africa during a period of extreme climate change.

Keywords: Eastern Africa, Kenya, Turkana, lithics, obsidian, pastoralism, mobility

\section{Introduction}

Past societies around the world repeatedly reconfigured their technologies to accommodate the challenges and opportunities of novel food-production strategies. In Africa, mobile lifeways that economically and ideologically focused on herding livestock emerged before plant agriculture (Marshall \& Hildebrand 2002). Mobile herding facilitated the expansion of human, animal and plant populations, contributing to the development of social and economic diversity in sub-Saharan Africa (Bollig et al. 2013; Prendergast et al. 2019). Broad geographic patterns were shaped by the specific solutions adopted by herders as they confronted new climatic and social situations. Stone-tool technologies were a primary component of early herder strategies, reflecting the ways in which these groups interacted

\footnotetext{
* Department of Archaeology, Max Planck Institute for the Science of Human History, Kablaische Strasse 10, 07745 Jena, Germany (Email: goldstein@shh.mpg.de)
}

(C) Antiquity Publications Ltd, 2019. This is an Open Access article, distributed under the terms of the Creative Commons Attribution licence (http://creativecommons.org/licenses/by/4.0/), which permits unrestricted re-use, distribution, and reproduction in any medium, provided the original work is properly cited. 
with their environments. The lithic record provides a means of connecting regional archaeological patterns to broader trajectories of African food production.

African pastoralism emerged in the Early Holocene Sahara, during a period of high rainfall and associated expansion of rivers, lakes and grasslands (Kuper \& Kröpelin 2006). Initially, people integrated herding into extant fisher-forager lifeways, while maintaining the widespread use of wavy-line pottery, barbed bone points and microlithic and bifacial toolkits (Sutton 1977; Holl 2005). As herding became more important, groups gradually increased their investment in systematic lithic raw-material acquisition, and reorganised their lithic chaîne opératoire (Cremaschi \& di Lernia 1999; Garcea 2005). Aridity in the early Middle Holocene pushed herders southward. In eastern Africa, domesticated cattle (Bos taurus), sheep (Ovis aries) and goats (Capra hircus) first appear at Lake Turkana in northern Kenya by 5000 cal BP (Marshall et al. 1984; Grillo \& Hildebrand 2013; Hildebrand et al. 2018).

Northern Kenya proved an important staging ground for the southward expansion of pastoralism (Bower 1991). As herders ventured farther from resource-predictable river valleys such as the Nile in search of grazing, they encountered unpredictable and drought-prone environments already occupied by hunter-gatherers (e.g. Robbins 1979; Lahr et al. 2016; Beyin et al. 2017). Hildebrand et al. (2018) have identified that, in part, herders responded to these conditions by developing new social institutions, including the unprecedented tradition of constructing monumental 'pillar-site' cemeteries. Despite evidence for climatic and social change on this 'moving frontier' (Sawchuk et al. 2018), many aspects of herder economic strategies remain unclear. This is due predominantly to the challenge of differentiating herder and hunter-gatherer toolkits, and identifying meaningful variation within or between assemblages (Hildebrand et al. 2011; Wright \& Forman 2011; Wright et al. 2015, 2016).

This article explores the lithic technological organisation of the earliest herders in northern Kenya. The aim is to demonstrate the viability of lithic analyses in answering questions of local and regional significance: what are the technological relationships between habitations and special-purpose pillar sites? What do technological patterns reveal about the broader economic strategies associated with early herding in Turkana? Analyses of stone tools from new and previously unpublished assemblages from Lake Turkana are presented, followed by a discussion of the implications for the development of socio-economic mechanisms that, eventually, ensured the long-term resilience of herder lifeways in eastern Africa.

\section{Early herding sites in northern Kenya}

Debates concerning the origins of the earliest herders in Turkana have largely overshadowed discussion of how these economies operated. Due in part to the ephemeral nature of mobile herders on the landscape, only two habitation sites (Dongodien and Gaji2, see Figure 1) with domesticated cattle and caprines securely dated to $4500-4000 \mathrm{cal} \mathrm{BP}$ are currently known (Barthelme 1981). Faunal evidence indicates that the inhabitants of these sites were diversified pastoralists who balanced herding with fishing (Marshall et al. 1984). The continuity in use of both aquatic resources and microlithic toolkits (made from local basalt and chert) through the Early to Middle Holocene has been argued to show that local huntergatherer-fishers were integrating livestock into their subsistence economies (Ambrose 1984; Barthelme 1985).

(C) Antiquity Publications Ltd, 2019 


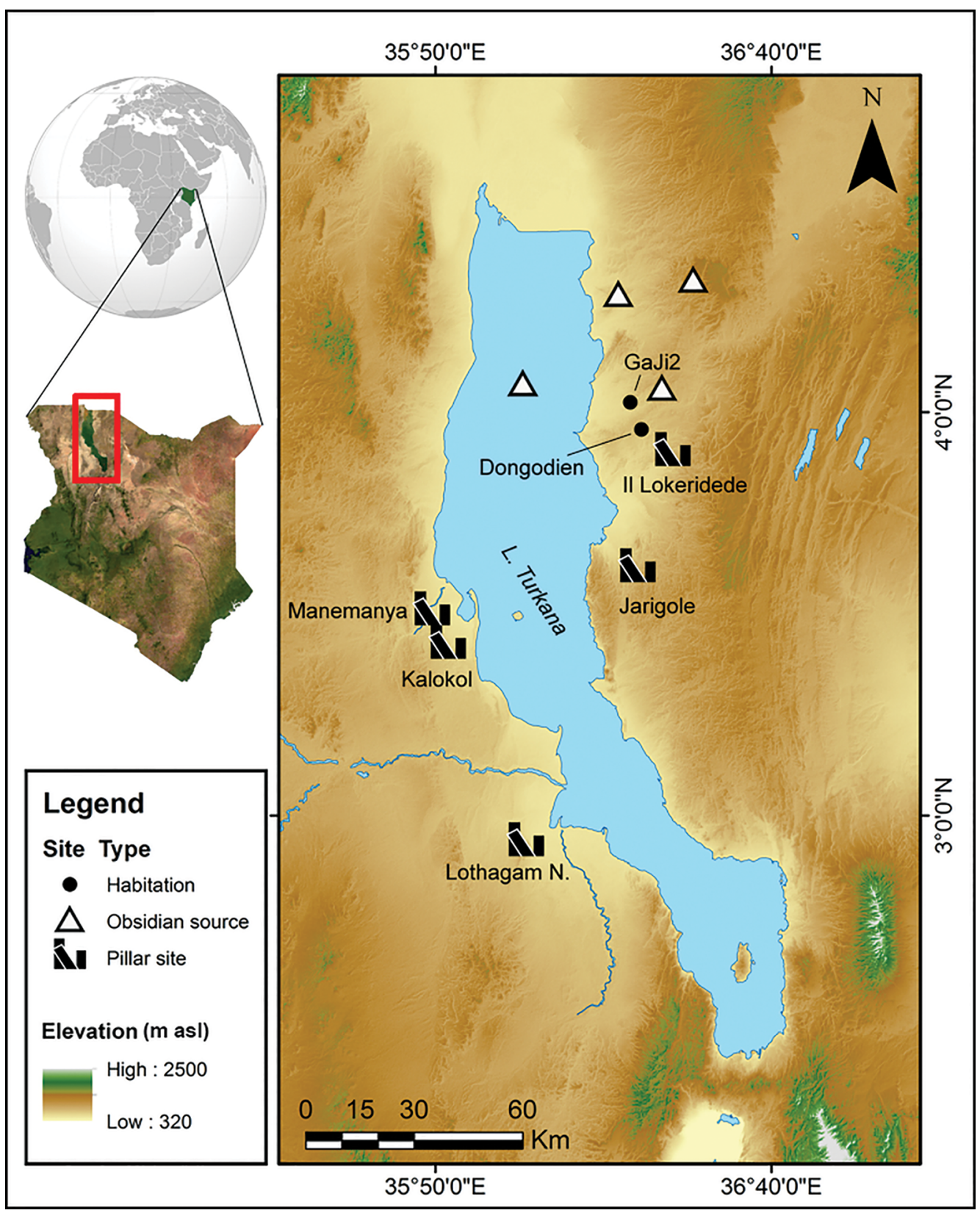

Figure 1. Nderit herder sites and obsidian sources mentioned in text (elevation data from NASA/JPL Shuttle Radar Topography Mission 1).

A combination of new ceramic styles, burial traditions and patterns of obsidian transport however, may suggest a more substantial economic shift in association with the first domesticated animals (Nelson 1973; Grillo \& Hildebrand 2013; Wright et al. 2015). At Dongodien, evidence for early livestock is associated with a new, highly decorated style of ceramics, termed

(C) Antiquity Publications Ltd, 2019 


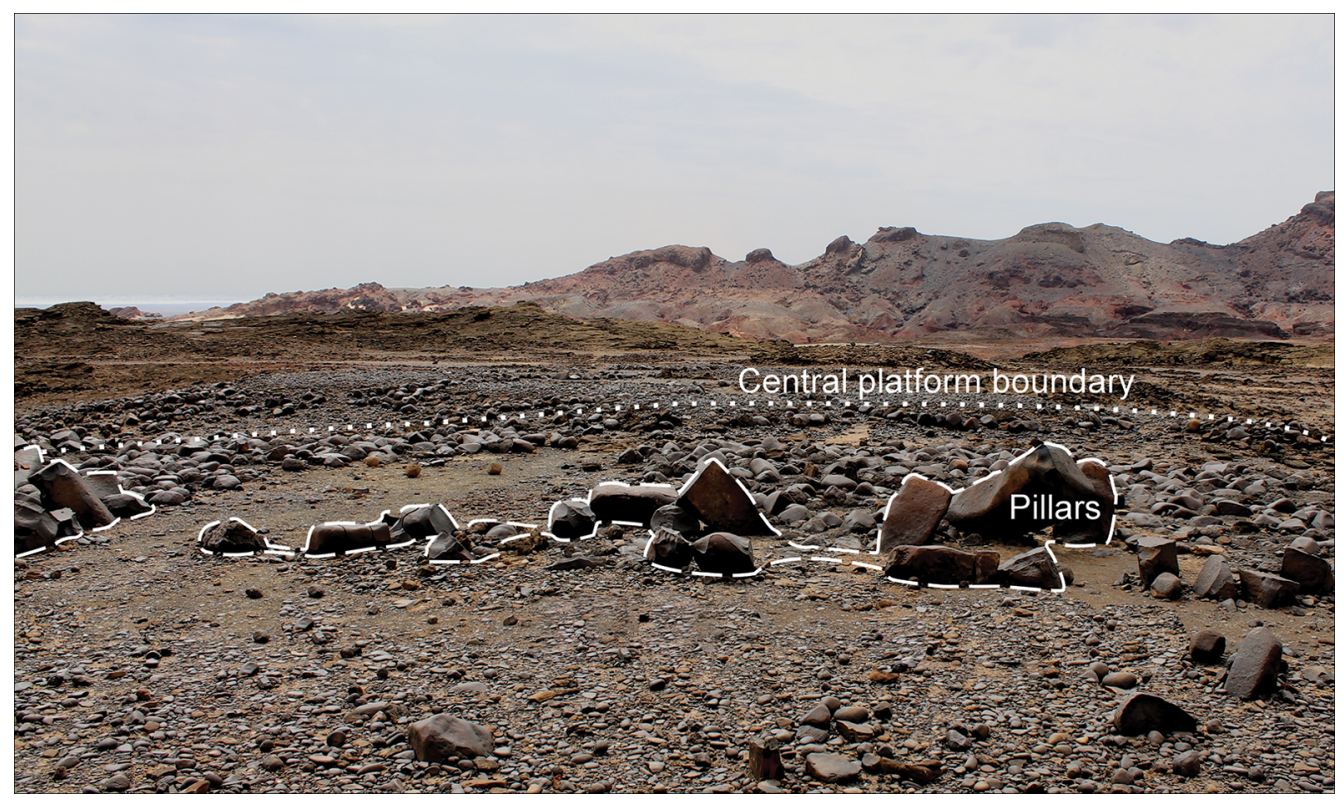

Figure 2. Lothagam North pillar site, view facing east towards Lake Turkana, Kenya (photograph by S. T. Goldstein).

'Nderit ware' that differs from the plain and wavy-line pottery traditions of local fisherforagers (Wandibba 1977; Barthelme 1981). Nderit ceramics are also present at several of, but not all, the monumental cemeteries marked by natural basalt pillars that appear around Turkana after 5300 cal BP (Hildebrand \& Grillo 2012; see Figure 2). The construction of large burial mounds marked with rows of translocated natural basalt pillars at Lothagam North and Jarigole is attributed to early herders, based on material culture similarities with Dongodien (Nelson 1995; Gifford-Gonzalez 2005; Hildebrand et al. 2011; Hildebrand et al. 2018). In addition, caprines have been identified in the faunal assemblage from Lothagam North (Hildebrand et al. 2018) and clay cattle figurines have been recovered from Jarigole (Figure 3; Nelson 1995).

Other, smaller pillar sites, such as Lothagam West and Kalokol have yielded no clear connections to herders, and differ from the Nderit sites in their organisation and material culture (Hildebrand et al. 2011). Extant samples of lithics from such sites are too small to be statistically significant, and preliminary analysis suggests that a few of these assemblages are heavily weathered Middle Stone Age (c. 250-25 kya) artefacts. Whatever these other, smaller, sites may represent, the tradition(s) of pillar-site construction and associated Nderit pottery use disappeared from Turkana after 4000 BP. This coincides with another retreat of lake water levels and a prolonged shift towards more arid conditions across the Turkana Basin (van der Lubbe et al. 2017). The few known post-Nderit sites attest to some continuation of mixed small-scale herding, fishing and foraging (Phillipson 1977, 1984; Wright et al. 2015).

Dongodien, Jarigole and Lothagam North are the only herding sites that have yielded large lithic assemblages and Nderit pottery securely dated to this early phase of herding (C) Antiquity Publications Ltd, 2019 


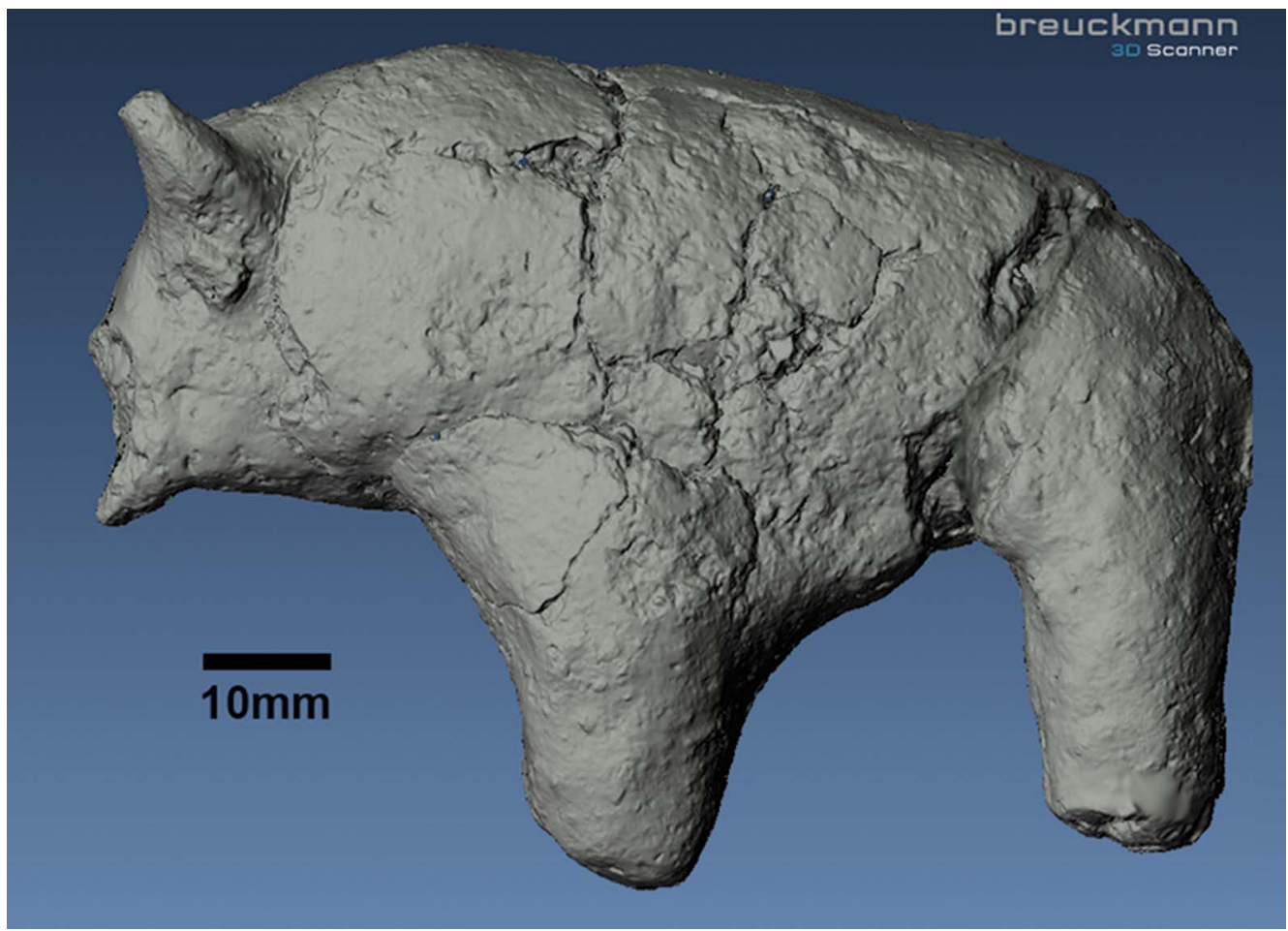

Figure 3. Three-dimensional scan of fired-clay cow figurine from Jarigole (figure by S.T. Goldstein).

(5000-4000 BP). Similarities between the sites in ecological settings and known distances to obsidian sources permit reconstructions of lithic technological strategies - and thus the broader economies - of the earliest herders in the Lake Turkana Basin.

\section{Lithic analysis}

Confusion over the variability of Middle Holocene lithic signatures across eastern Africa may result from a legacy of identifying industries based on tool types and ratios, rather than technological strategies (Nelson 1973; Barthelme 1985). Approaches focused on site ecologies, quantitative morphologies and reduction sequences among herders and foragers are better developed in southern Kenya, where they have helped to clarify culture-history and economic variability (e.g. Ambrose 1998). The present research operates within a theoretical framework that considers stone-tool assemblages to reflect intentional systems of manufacture, maintenance and discard (Binford 1979; Nelson 1991; Andrefsky 2009). Patterns of flake production and tool use are structured by decisions weighing cultural, economic and environmental considerations within a cost-benefit framework. Choices about flake shape, striking-platform size and intensity of tool use reflect raw-material conservation strategies as related to mobility (Shott 1986; Nelson 1991). In general, highly mobile groups favour more formal industries that maximise the utility of the stone-tool supply that they carry with them; less mobile groups not under such curation pressures expediently reduce local

(C) Antiquity Publications Ltd, 2019 
raw materials. Variety in tool types and morphological variation within type-categories reflect ongoing and anticipated tool needs (i.e. craft production, hunting or other subsistence tasks). In summary, technological organisation reflects the degrees to which people were planning for, and investing in, different activities, such as herding, fishing, hunting and gathering across the landscape.

To understand the conditions that structured the lithic choices of ancient herders around Lake Turkana, I analysed lithic material from all three early herding sites that, to date, have yielded large, securely dated, tool and debitage assemblages. These are the single habitation site of Dongodien (Barthelme 1981; Ashley et al. 2017) and the pillar-cemetery sites at Jarigole and Lothagam North (Nelson 1995; Hildebrand et al. 2011, 2018). Assessment of the cemetery assemblages demonstrates that they reflect construction, maintenance and mortuary activity, rather than being secondary deposits brought in as fill (Nelson 1995). Comparing assemblages from habitation and special-purpose sites is necessary given the lack of comparative assemblages from dated sites, but also presents an opportunity to identify social dimensions in technological variation (for specific details of the excavations, the archaeological contexts, sampling strategies and methods of lithic analysis, see the online supplementary material (OSM)).

\section{Technological organisation}

Raw material selection is the basis for the development of technological strategies. It has implications for group mobility in terms of more mobile societies with less predictable access to stone sources tending to favour high-quality raw materials that allow for greater utility of tool production per unit of stone (Andrefsky 2009). Cobbles of high-quality chert can be found in nearby streambeds around Jarigole and Dongodien, and there are pockets of tabular chert eroding from the western side of the Lothagam ridge, adjacent to Lothagam North (Figure 4). Geochemical sourcing shows that primary obsidian sources are distributed along the north-eastern lake basin (Nash et al. 2011; Brown et al. 2013; see Figure 1). Early Holocene hunter-gatherer-fishers across northern Kenya made ample use of abundant, local lavas and cherts. Obsidian, if present at all, typically constitutes only a small percentage of assemblages, and is often restricted to heavily deflated and reworked surface or near-surface contexts (e.g. Robbins 1979). Hunter-gatherer-fishers produced a highly diverse range of lithic industries, with sites exhibiting expedient flake technologies, diverse microlithic toolkits and sometimes mixes of both (Robbins 1972, 1979; Barthelme 1977; Phillipson 1977; Beyin 2011; Beyin et al. 2017).

In contrast to the Early Holocene patterns, obsidian constitutes the vast majority (72-92 per cent) of the lithic material at Middle Holocene sites in the Lake Turkana Basin associated with early herding (Table 1). This signals a shift from down-the-line or incidental access to obsidians, to systematic or even semi-formalised acquisition systems. Ndiema et al. (2010) have proposed that newly formed obsidian exchange networks facilitated the movement of obsidian around, or across, Turkana after $c$. $5000 \mathrm{BP}$. Investment in new social systems to access high-quality raw material highlights the importance of predictable flake production and microlithisiation. While these features were certainly present across Late Stone Age (c. 25-5 kya) eastern Africa, their intensification at this time reflects major shifts in economic

(C) Antiquity Publications Ltd, 2019 


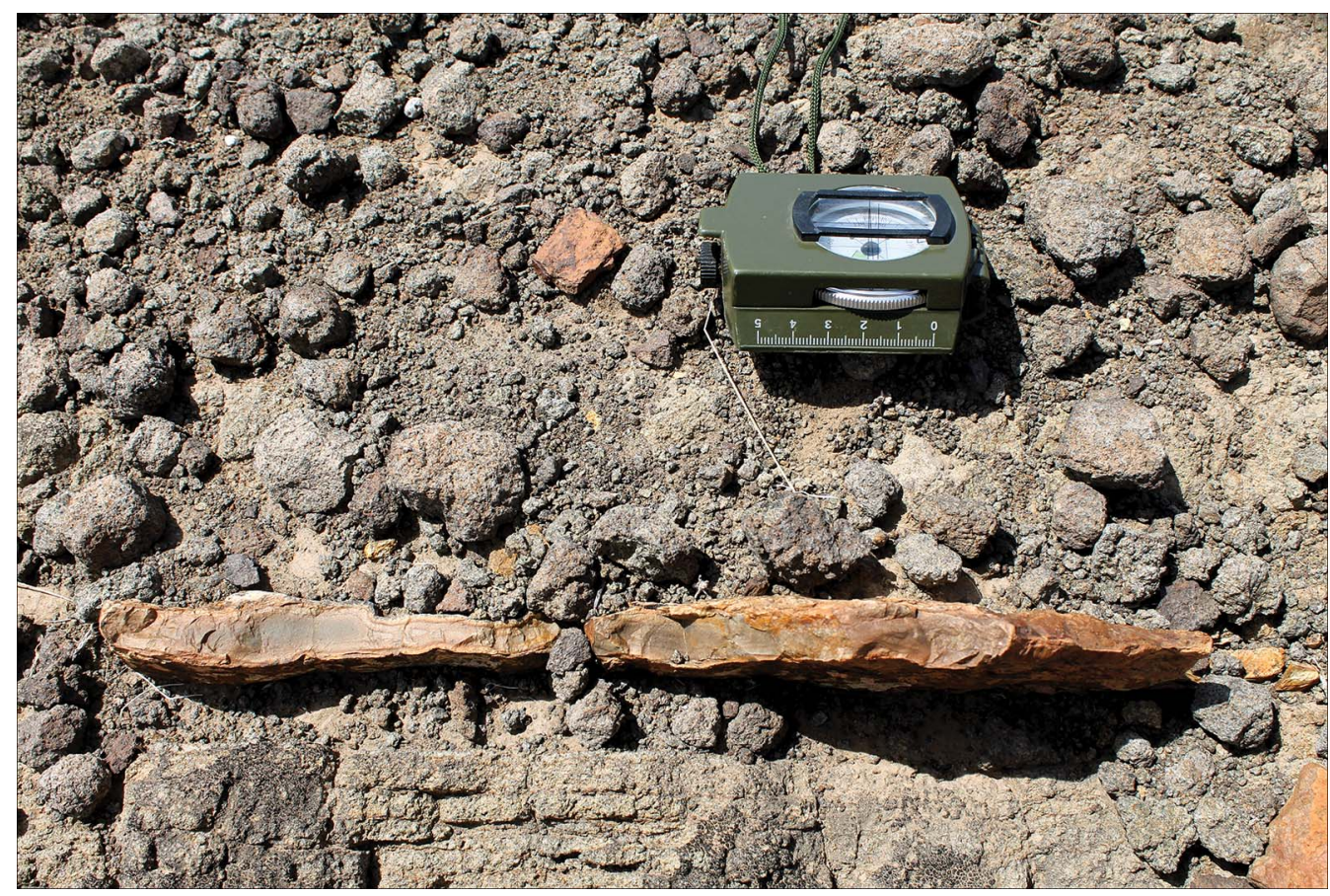

Figure 4. Tabular chert eroding from the western ridge of Lothagam, near Lothagam North (photograph by S.T. Goldstein).

Table 1. Radiocarbon chronology and lithic raw-material composition for the sample sites.

\begin{tabular}{|c|c|c|c|c|c|c|c|c|}
\hline Site & Lab \# & Material & Uncal. BP & Cal $\mathrm{BP}^{1}$ & $\mathbf{n}$ & $\begin{array}{c}\text { Obsidian } \\
(\%)\end{array}$ & $\begin{array}{c}\text { Chert } \\
(\%)\end{array}$ & $\begin{array}{c}\text { Volcanic } \\
(\%)\end{array}$ \\
\hline \multirow[t]{4}{*}{ Dongodien } & P-2610 & Charcoal & $3960 \pm 60$ & 4777-4184 & 264 & 85 & 10.9 & 2 \\
\hline & Beta- $252053^{3}$ & Charcoal & $4180 \pm 40$ & $4840-4580$ & & & & \\
\hline & Beta-252054 3 & Charcoal & $4240 \pm 40$ & 4869-4628 & & & & \\
\hline & Beta- $252056^{3}$ & Charcoal & $4180 \pm 40$ & $4840-4580$ & & & & \\
\hline \multirow{5}{*}{$\begin{array}{l}\text { Lothagam } \\
\text { North }\end{array}$} & ISGS-A1491 ${ }^{4}$ & OES & $4385 \pm 15$ & $5033-4870$ & 492 & 92.1 & 4.1 & 3.9 \\
\hline & ISGS-A1492 & OES & $4265 \pm 15$ & $4855-4830$ & & & & \\
\hline & ISGS-A1505 & OES & $4165 \pm 20$ & 4827-4618 & & & & \\
\hline & ISGS-A2624 & Charcoal & $4280 \pm 15$ & $4861-4835$ & & & & \\
\hline & ISGS-A2625 & OES & $3845 \pm 20$ & 4405-4154 & & & & \\
\hline \multirow[t]{4}{*}{ Jarigole } & AA85131 ${ }^{5}$ & OES & $4381 \pm 39$ & $5212-4853$ & 245 & 72.1 & 8.6 & 19.3 \\
\hline & AA851325 & OES & $4251 \pm 39$ & $4875-4630$ & & & & \\
\hline & AA85133 & OES & $4401 \pm 39$ & $5270-4857$ & & & & \\
\hline & AA85134 & OES & $4146 \pm 53$ & $4829-4529$ & & & & \\
\hline
\end{tabular}

\footnotetext{
${ }_{1}^{1}$ Calibrations employ OxCal 4.3 with IntCal13 Northern Hemisphere curve (Bronk Ramsey 2009; Reimer et al. 2013);
}

${ }^{2}$ Barthelme (1985); ${ }^{3}$ Ashley et al. (2017); ${ }^{4}$ Hildebrand et al. (2018); ${ }^{5}$ Hildebrand \& Grillo (2012).

(C) Antiquity Publications Ltd, 2019 
organisation. In other case studies around the world, similar shifts in raw-material selection are associated with pressure to maximise the efficiency of reducing a limited stone supply stemming from increased group mobility (e.g. Wallace \& Shea 2006; Andrefsky 2009).

People at all three early herding sites used obsidian in the same way: in the manufacture of blade blanks for formal tools, following a single operational sequence (Figures 5-7) (Table 2). Other raw materials were flaked expediently, without a preference for any flake shape. Roughly 92 per cent of obsidian blades across all three assemblages exhibit parallel flake-scars, indicating maintenance of single-platform pyramidal blade cores (Table 3). Identical distributions for blade curvatures across the sites (Kruskal-Wallis $\mathrm{H}=0.4538, \mathrm{p}=0.80$; Figures 8A $\&$ S1) reflect further consistency in the morphology of core release surfaces, and thus core design. Striking platforms are consistently small and intensively prepared through abrasive grinding to remove loose material before subsequent flaking.

Reconstruction of core-reduction strategies in the assemblages reflects a shared chaine opératoire (Figure 9). Obsidian cores begin with pyramidal shapes, with the single striking platform that retains cortex (Figure 9A-B \& D). Average blade curvatures at all three sites increase through the reduction sequence along a similar regression line, suggesting the consistent management of core shape (see the OSM). Once reduced to lengths of $\sim 20 \mathrm{~mm}$, cores were too small for continued bladelet production. At this stage, knappers switched to bipolar production techniques, producing outils écaillés, or 'splintered-pieces'. Expended bipolar pieces make up a greater proportion of cores abandoned at Jarigole and Lothagam North (Table 4). Although pyramidal cores were more often abandoned before they reached the bipolar stage at Dongodien, differences in core proportions are not significant $\chi^{2}=11.55$, Monte Carlo $\mathrm{p}=0.165$, $\mathrm{df}=8$ ). Intensity of core reduction is reflected in the differences between the volumes of unworked obsidian nodules from a source outcrop and recovered cores (Figure 8B).

While fundamental aspects of lithic technological strategies are consistent across early herder sites in Turkana, there is some variability in how these strategies were deployed. Blade lengths are significantly higher at Lothagam North compared to Dongodien and Jarigole (Figure $8 \mathrm{C}$, Kruskal-Wallis $\mathrm{H}=10.3, \mathrm{p}=0.005$ ), although the differences are not significant if several large refitting blades associated with a burial are removed from the analysis (Kruskal-Wallis $\mathrm{H}=5.17, \mathrm{p}=0.075$ ) (Figure 10). Blade-width distributions display the opposite pattern, with lower values at Lothagam North (Figures 8D \& S2). Taken together, the length and width patterns of obsidian blades do not demonstrate a clear relationship with distance from raw-material sources, as would be expected with simple down-the-line exchange. Instead, this non-linear metric variation is more consistent with more organised lithic-provisioning behaviours.

Although striking platforms on obsidian blades are universally small, their relationships with blade metrics vary between sites. For pillar-site assemblages, platform size is a strong predictor of both blade width and thickness (Pearson's $\mathrm{R}^{2}=0.70, \mathrm{p}<0.05$ and Pearson's $\mathrm{R}^{2}=$ $0.71, \mathrm{p}<0.05$, respectively). At the Dongodien habitation site, there are no correlations between platform size and metrics (Pearson's $\mathrm{R}^{2}=0.49, \mathrm{p}=0.01$, and Pearson's $\mathrm{R}^{2}=0.18$, $\mathrm{p}=0.36$, for width and thickness respectively).

Tool use is the final relevant dimension of lithic variability. I differentiate between formal, shaped tools and flakes with only casual retouch or edge damage. Lothagam North is the only site where these categories are equally represented. Informal modified pieces tend to be made (C) Antiquity Publications Ltd, 2019 


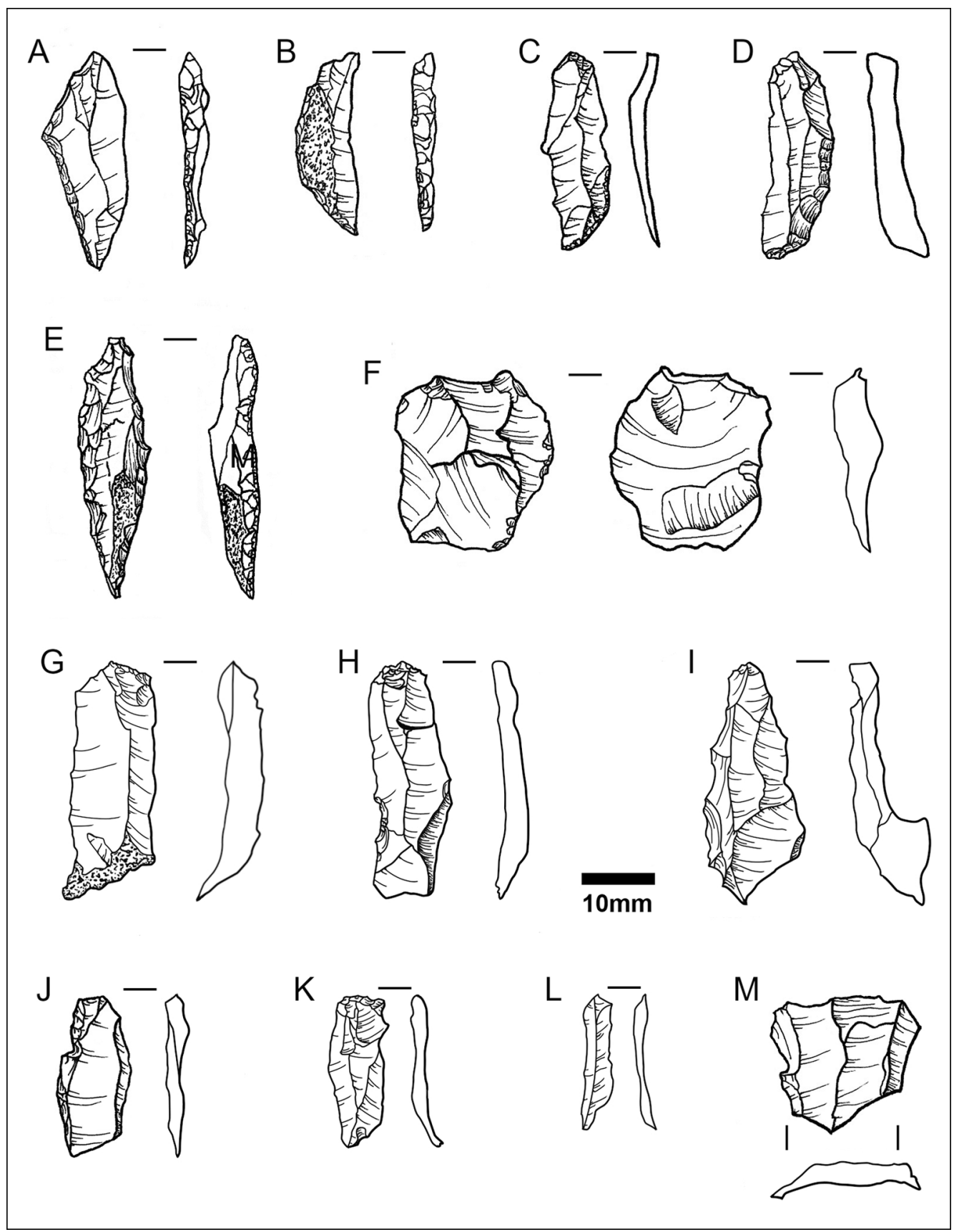

Figure 5. Lithics from Dongodien: $A-B$ ) backed crescents; $C-D$ ) oblique truncations; E) awl; F) core-tablet; $G-L$ ) representative bladelets; $M$ ) lateral or 'flanc' removal from a pyramidal core (figure by S.T. Goldstein).

from local raw-material sources, whereas obsidian blades are used as blanks in nearly all formal tool production. This reinforces the distinction between the structured and systematic use of obsidian by early herders, and the more opportunistic use of obsidian.

(C) Antiquity Publications Ltd, 2019 


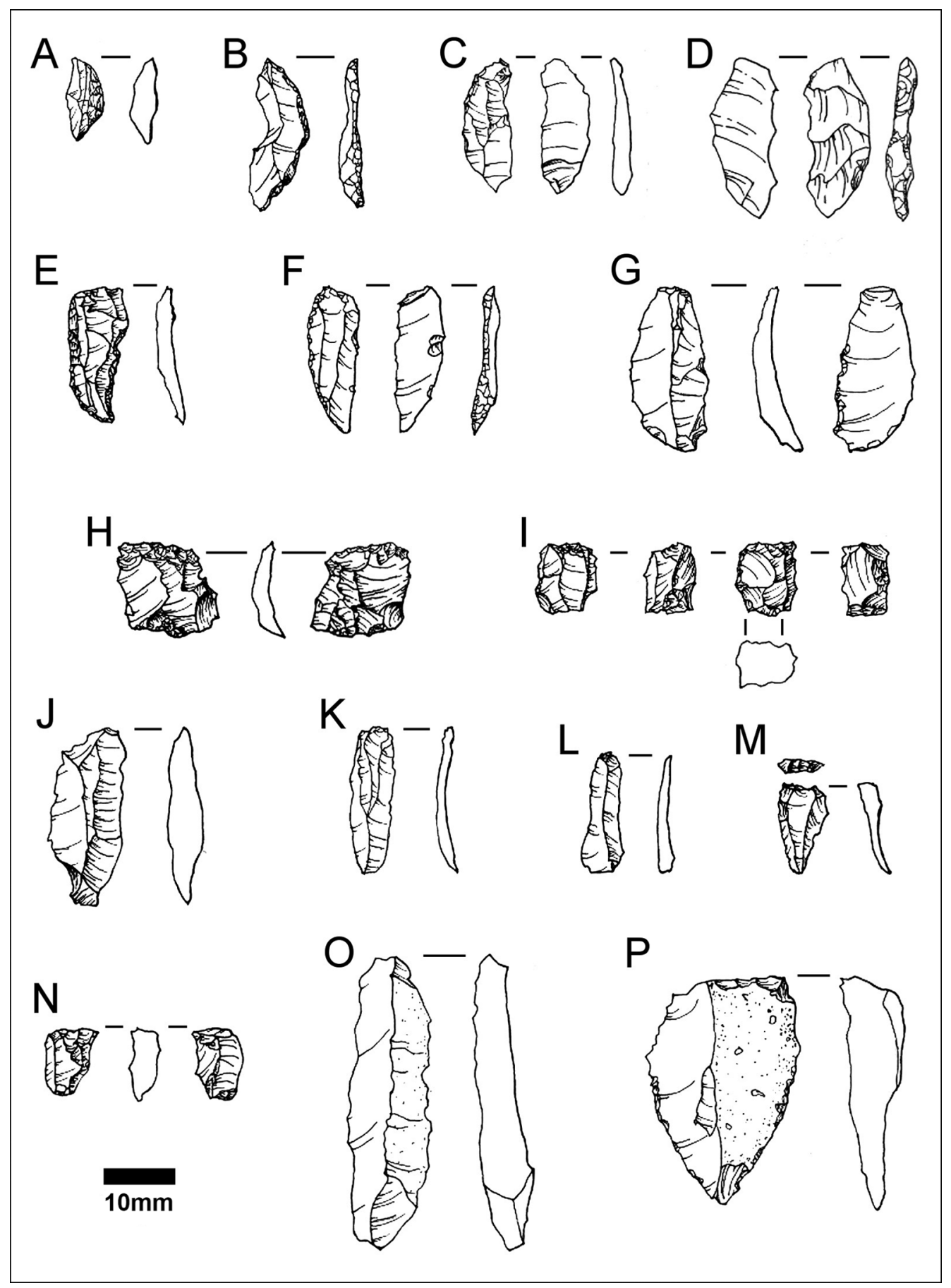

Figure 6. Lithics from Jarigole: $A-D)$ backed crescents; $E-F)$ oblique truncations; $G$ ) utilised flake; $H-I)$ outils écaillés/ bipolar cores; $J-M$ ) typical bladelets; $N$ ) bipolar flake; $O-P$ ) large flakes. $A-N$ are obsidian, $O-P$ are basalt (figure by S.T. Goldstein).

(C) Antiquity Publications Ltd, 2019 


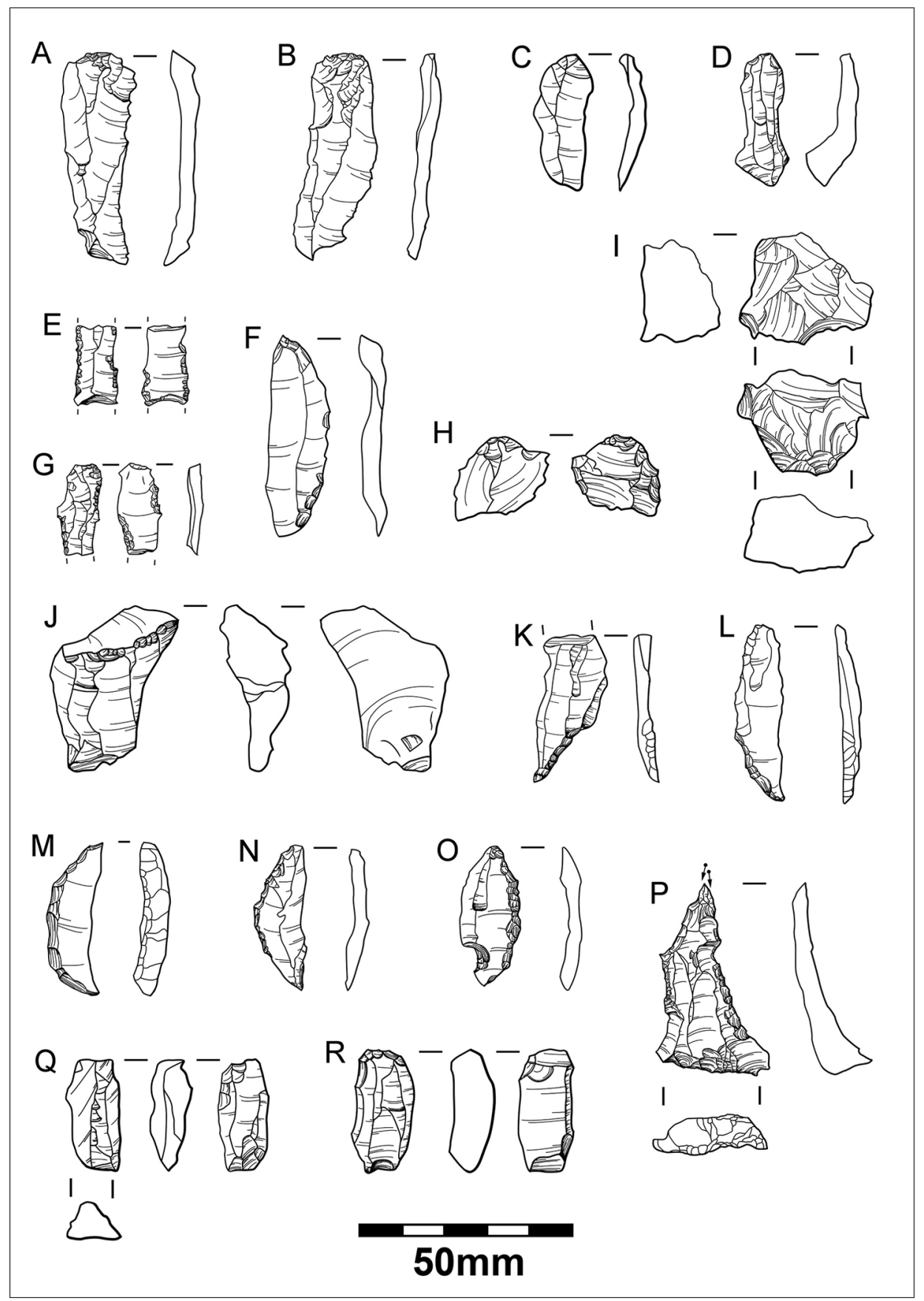

Figure 7. Lithics from Lothagam North: A-D) typical bladelets; E-F) utilised bladelets; H) outil écaillés/ bipolar core; I) multidirectional core; J) opposed platform removal; $K-L$ ) oblique truncations; $M-O)$ backed crescents; $P$ ) combination endscraper/burin; Q-R) bipolar cores. All pieces are obsidian (figure by S.T. Goldstein). 
Table 2. Summary of lithic assemblages from early herder sites.

\begin{tabular}{lccccccccc}
\hline Site & Cores & $\begin{array}{c}\text { Core } \\
\text { modification }\end{array}$ & Flakes Blades & $\begin{array}{c}\text { Bipolar } \\
\text { flakes }\end{array}$ & $\begin{array}{c}\text { Shaped } \\
\text { tools }\end{array}$ & $\begin{array}{c}\text { Utilised } \\
\text { pieces }\end{array}$ & $\begin{array}{c}\text { Total } \\
(\mathbf{n})\end{array}$ & $\begin{array}{c}\% \\
\text { tools }\end{array}$ \\
\hline Dongodien & 32 & 9 & 47 & 165 & 4 & 25 & 12 & 294 & 12.6 \\
Lothagam N. & 46 & 12 & 89 & 203 & 53 & 43 & 46 & 492 & 18.1 \\
Jarigole & 21 & 5 & 73 & 100 & 9 & 28 & 9 & 245 & 13.5 \\
\hline
\end{tabular}

Table 3. Flake-scar orientation proportions for obsidian blades.

\begin{tabular}{lccccc}
\hline Site & Parallel & Opposed & Rotated & Multi-direct. & Total \\
\hline Dongodien & $92.1 \%$ & $3.0 \%$ & $3.0 \%$ & $1.8 \%$ & 165 \\
Lothagam N. & $92.8 \%$ & $5.9 \%$ & $0.0 \%$ & $1.3 \%$ & 153 \\
Jarigole & $92.0 \%$ & $2.0 \%$ & $6.0 \%$ & $0.0 \%$ & 100 \\
\hline
\end{tabular}

Formal assemblages from all three sites comprise a consistently narrow range of tool types (Table 5). The toolkits from Dongodien are predominately backed microliths (75-92 per cent), confirming Barthelme's (1981) observations. Crescents and truncations are the most common forms of backed tools (see Figures 5-7). The average sizes of crescentswhich were probably used in composite projectiles or cutting tools-are consistent with values for the earliest herders in southern Kenya (Ambrose 2002). Crescents are twice as abundant at Dongodien, whereas scrapers and awls are more common at Jarigole. This difference is partially driven by the unusual presence of chert awls, presumably for bead production, in the Jarigole assemblage (Nelson 1995: 55). Despite minor differences in ratios, the overall consistency in tool types, morphologies and sizes across all three sites suggest that they reflect the same toolkit and tool-use strategies.

\section{Discussion}

A comparative analysis of lithic assemblages from three early pastoralist sites provides new and valuable insights for addressing major questions concerning the spread of herding into northern Kenya. First, this analysis demonstrates that communities who lived at Dongodien, and those who constructed and used the Jarigole and Lothagam North pillar sites, all shared a distinct technological tradition that set them apart from other Late Stone Age sites in the region. Early herders at all three sites employed the same chaine opératoire to produce morphologically consistent blade cores and bladelet blanks for formal tools from obsidian, while local raw materials were reduced and used expediently for informal tools. This contrasts with Early Holocene hunter-gatherer-fisher assemblages, which attest the manufacture of diverse microlithic and large-flake toolkits on local cherts and basalts (see Phillipson 1977; Robbins 1979; Barthelme 1985; Beyin 2011; Beyin et al. 2017). While earlier hunter-gatherers used obsidian occasionally, the high proportions of obsidian at early herding sites have no precedent in the Turkana Basin.

(C) Antiquity Publications Ltd, 2019 


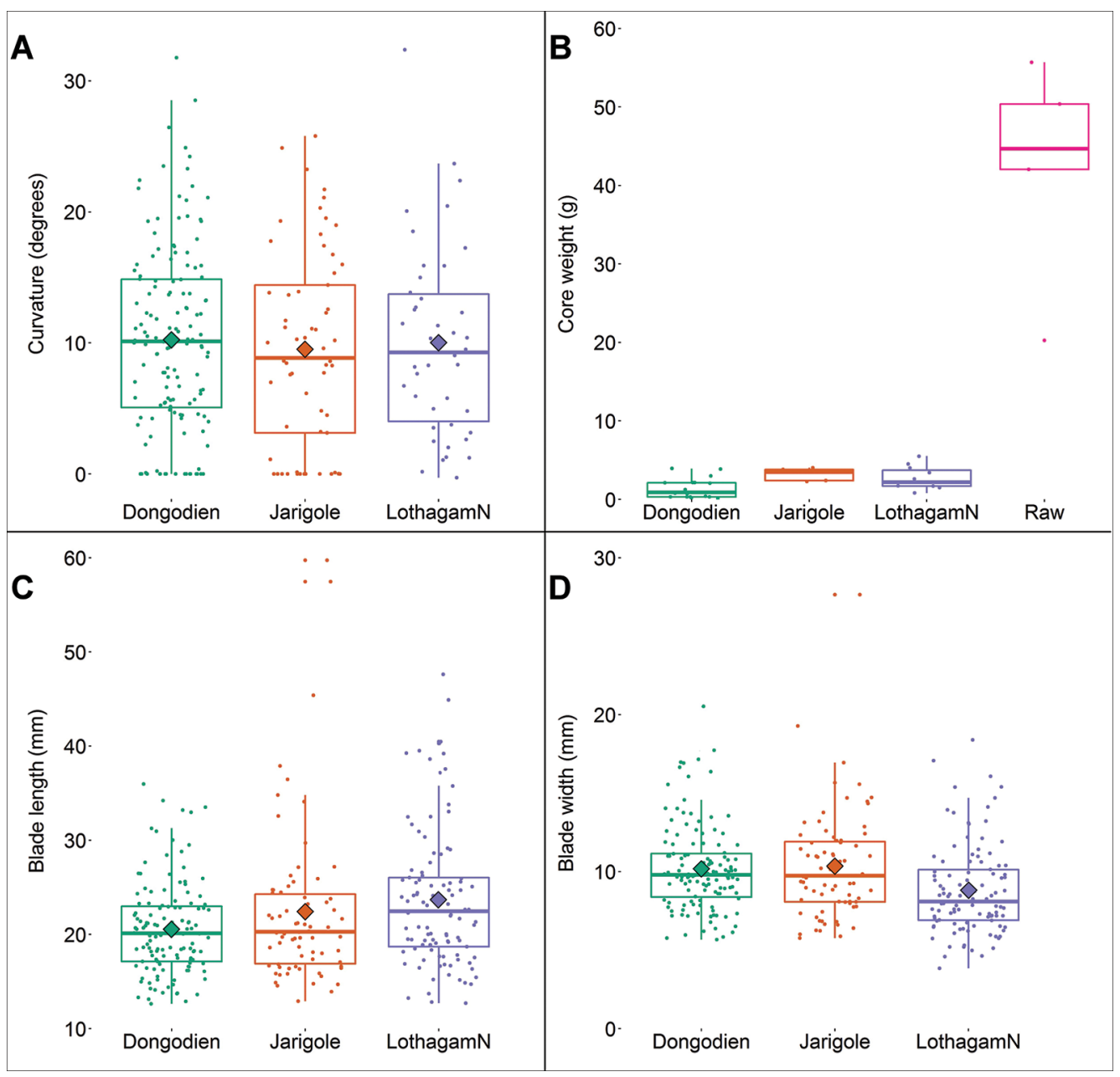

Figure 8. Boxplots of obsidian blade curvature (A); estimated obsidian core volume (B); blade width (C); and blade thickness (D). Diamonds = sample mean. Volumes for unworked nodules in $(B)$ are taken from five nodules in the National Museums of Kenya collected by John Barthelme (figure by S.T. Goldstein).

The production of uniform, highly transportable blade blanks requires access to homogeneous raw materials with highly predictable fracture mechanics. Obsidian was preferred by many stone-tool-using societies around the world, both because it possesses these attributes and because it produces razor-sharp edges when flaked (e.g. Shackley 1988; Ambrose 2012; Tripcevich \& Contreras 2013).

These properties of obsidian allow for the manufacture of formal, prepared blade cores, which are generally associated with more mobile societies (Shott 1986; Wallace \& Shea 2006). Uniform blanks produced from these blade cores can be used to make a wide variety of tools, offering increased flexibility to exploit a broader range of resources and environments (Nelson 1991). Being able to respond rapidly to changing climatic conditions would have been advantageous for communities whose livelihoods depended on their ability to move

(C) Antiquity Publications Ltd, 2019 


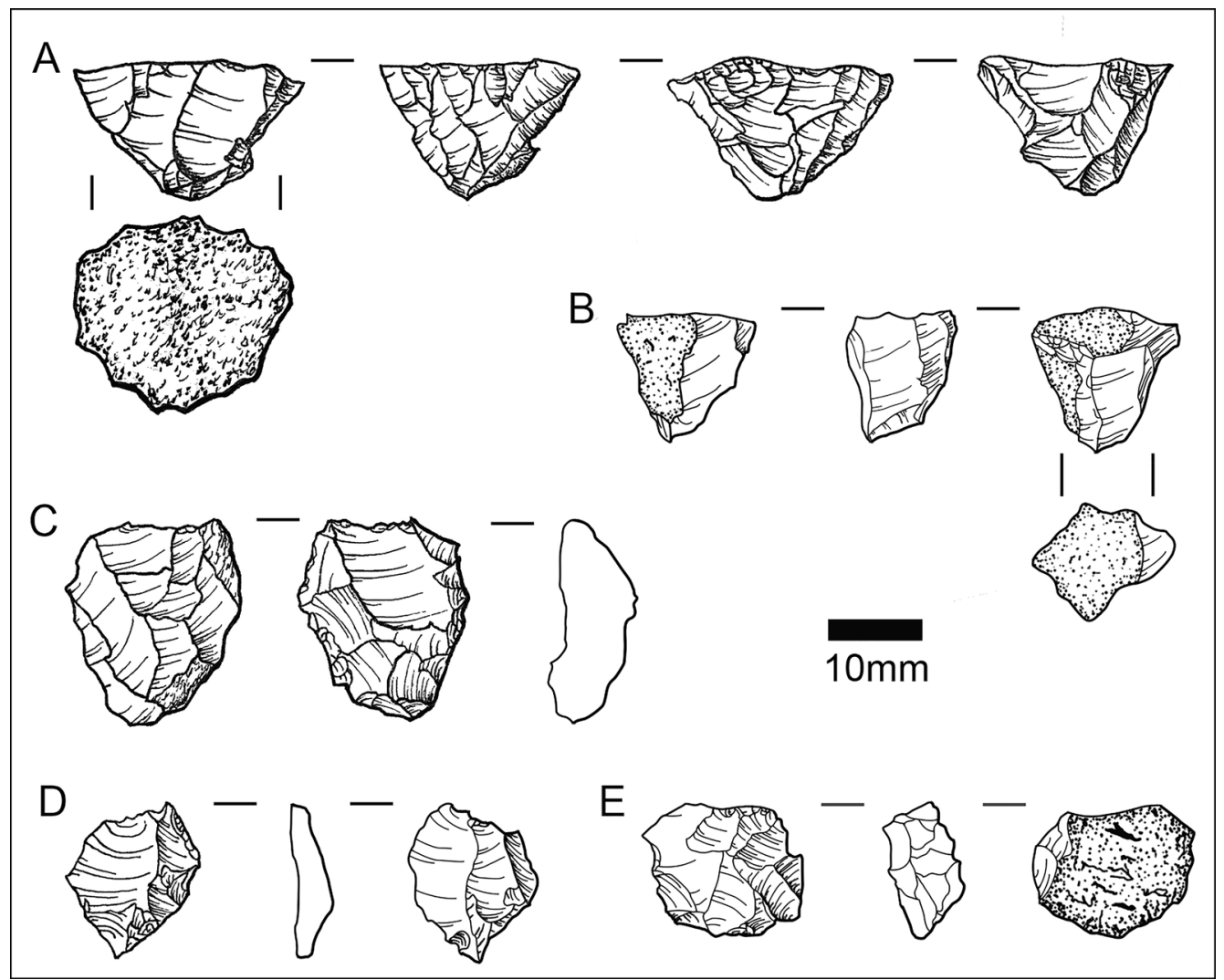

Figure 9. Cores from Dongodien: A-B) pyramidal bladelet cores with cortical platforms; C) multi-directional bifacial core; D) bipolar core; E) bi-directional core (figure by S.T. Goldstein).

Table 4. Core proportions by platform type.

\begin{tabular}{|c|c|c|c|c|c|c|c|c|}
\hline \multirow[b]{2}{*}{ Site } & \multicolumn{4}{|c|}{ Backed pieces/'microlithic' } & \multicolumn{3}{|c|}{ Other } & \multirow[b]{2}{*}{ Total } \\
\hline & Crescents & $\begin{array}{l}\text { Oblique } \\
\text { truncations }\end{array}$ & $\begin{array}{l}\text { Lateral } \\
\text { truncations }\end{array}$ & $\begin{array}{l}\text { Other } \\
\text { backed }\end{array}$ & Awls & Scrapers & $\begin{array}{l}\text { Modified } \\
\text { pieces }\end{array}$ & \\
\hline Dongodien & $40.0 \%$ & $36.0 \%$ & $4.0 \%$ & $12.0 \%$ & $4.0 \%$ & $4.0 \%$ & $0.0 \%$ & 25 \\
\hline Lothagam N. & $23.3 \%$ & $30.2 \%$ & $7.0 \%$ & $16.3 \%$ & $2.3 \%$ & $4.7 \%$ & $16.3 \%$ & 43 \\
\hline Jarigole & $25.0 \%$ & $21.4 \%$ & $7.1 \%$ & $21.4 \%$ & $10.7 \%$ & $10.7 \%$ & $3.4 \%$ & 28 \\
\hline
\end{tabular}

livestock within a heterogeneous and ever-changing distribution of rain-fed pasture. The coarse volcanic stones used by many Early Holocene groups do not have these qualities and cannot be used to produce consistently uniform blade blanks. Site-by-site variation among Early Holocene hunter-gatherer-fishers may indicate more localised problem-solving.

Maintaining access to obsidian that had to be transported around, or across, Lake Turkana required not only increased mobility to and from obsidian sources, but also social investment (C) Antiquity Publications Ltd, 2019 


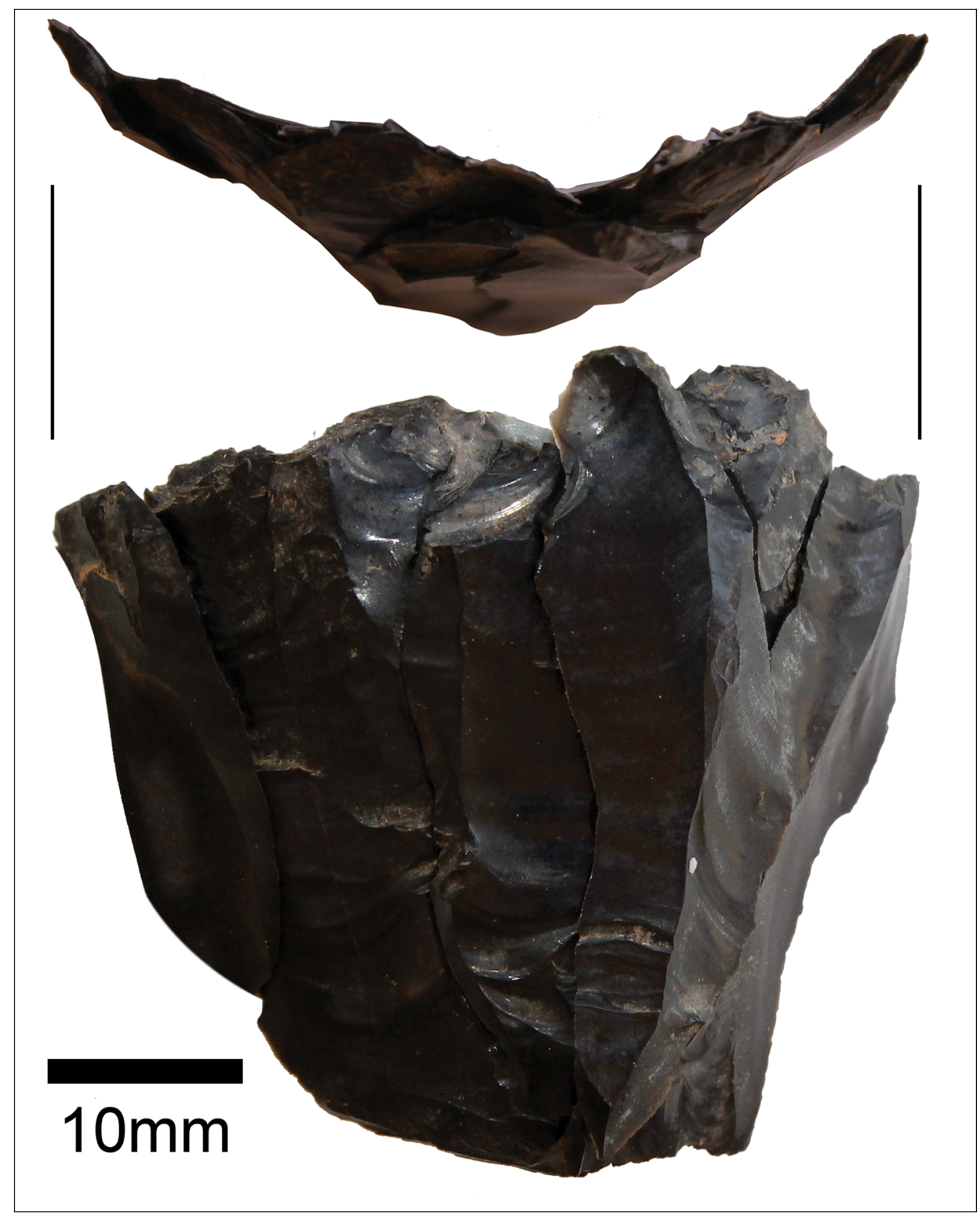

Figure 10. Refitting blade sequence from Lothagam North (photograph by S.T. Goldstein).

and community bonds. Even though groups were mobile, they could not guarantee access to obsidian within seasonal rounds organised around the location of grazing lands. Formal exchange relationships akin to historically documented stock-friend partnerships would have been an ideal solution, wherein individuals distribute livestock among kin and friends

(C) Antiquity Publications Ltd, 2019 
Table 5. Formal tool proportions.

\begin{tabular}{lcccccr}
\hline Site & Bipolar & $\begin{array}{l}\text { Single/ } \\
\text { parallel }\end{array}$ & $\begin{array}{l}\text { 2 platforms/ } \\
\text { opposed }\end{array}$ & $\begin{array}{l}\text { 2+ platforms/ } \\
\text { rotated }\end{array}$ & Multi-directional & Total \\
\hline Dongodien & $40.6 \%$ & $18.0 \%$ & $12.5 \%$ & $13.0 \%$ & $15.6 \%$ & 32 \\
Lothagam N. & $58.7 \%$ & $6.5 \%$ & $15.2 \%$ & $2.2 \%$ & $17.7 \%$ & 46 \\
Jarigole & $66.7 \%$ & $4.8 \%$ & $0.0 \%$ & $9.5 \%$ & $19.1 \%$ & 21 \\
\hline
\end{tabular}

as an insurance policy against the catastrophic loss of a herd (e.g. McCabe 2004). Similar risk-reduction networks were also developed by early herders in southern Kenya (Goldstein 2019). Indeed, the presence of identical lithic-reduction techniques across the three sampled sites indicates participation in a shared 'community-of-practice', wherein these skills and techniques were transmitted and maintained among spatially disparate groups (Goldstein 2018). Evidence for social networks surrounding lithic production reflect one facet of broader landscape-level cooperation that first appeared with early herders in Turkana, and culminated with the construction of megalithic cemeteries (Hildebrand et al. 2018).

While Dongodien, Lothagam North, and Jarigole share an identical lithic technological strategy, differences in tool ratios and reduction intensities signal subtle variations in how this strategy was deployed. Variation in core-reduction intensity between the mortuary sites of Lothagam North and Jarigole, for example, reflects differences in how material supply was managed during ritual/ceremonial activities at or around the monumental cemetery sites relative to domestic-use stone stockpiles at Dongodien. The variation in tool ratios is also a product of behavioural differences between sites. Activities involved in pillar-site construction, maintenance and human interment certainly differ from those expected for a herder habitation site. It is important to recognise that these minor differences within the early herding assemblages pale in comparison to the differences observed between herder assemblages and those of earlier hunter-gatherer-fishers.

The single greatest obstacle in exploring the relationships between herder and hunter-gatherer-fisher lithic assemblages continues to be the lack of published artefact inventories, measurements and technological descriptions from these site types. The present research establishes a clear and quantifiable lithic signature for the three sites with the best evidence for herding in northern Kenya. This can now be used to test this hypothesis in future analyses. Detecting, or failing to detect, local precedents for the mobility strategies that made herding lifeways possible in Turkana will add further lines of evidence for discussions about the processes by which pastoralism was first introduced into eastern Africa.

\section{Conclusion}

Technological strategies of the earliest herders in eastern Africa differ from those in regions where early food production entailed sedentary village agriculture. In the Lake Turkana region of northern Kenya, the earliest appearance of livestock and monumental mortuary complexes coincides with the adoption of obsidian as the dominant raw material, the development of consistent lithic reduction strategies and the formalisation of blade and tool

(C) Antiquity Publications Ltd, 2019 
morphologies. These changes reflect a reorientation and intensification of traits already present in Late Stone Age repertoires, highlighting the difficulty in disentangling lithic strategies based on qualitative attributes alone. Quantitative analyses reveal how herder assemblages deviate from those of hunter-gatherer-fishers, and that herder assemblages themselves exhibit a uniform technological strategy across the Lake Turkana area. This strategy appears to be oriented around preparing for heterogeneous environmental conditions and diverse economic tasks. If supported by further analyses, this would indicate that the introduction of herding fundamentally altered how certain peoples interacted with the landscape of the Turkana Basin.

The new technological strategies developed and employed by early herders were sustained by long-distance obsidian distribution networks. Exchange systems that appear after $5000 \mathrm{cal}$ BP appear to have been far more cohesive and consistent than any observed among earlier hunter-gatherers around Lake Turkana. Such systems formed only one component of a larger pattern of affiliation and cooperation among early herders. Strategic experiments in Turkana, whether successful or not, probably conditioned how herders responded to similar environmental, economic and social challenges as lifeways based on cattle, sheep and goats subsequently spread throughout eastern and southern Africa (Ambrose 1984; Gifford-Gonzalez 2005; Marshall et al. 2011; Sadr 2015). Further comparative analyses of African archaeological data at the regional level will foster a more holistic understanding of how the spread of food production shaped population histories, social systems and human-environment interactions, both in Africa and around the world.

\section{Acknowledgements}

I wish to thank the National Museums of Kenya for permission and assistance, especially E. Ndiema and P. Kiura. I am grateful to E. Hildebrand and K. Grillo, the directors of the Later Prehistory in West Turkana project, who invited me to participate in research at Turkana. The suggestions of anonymous reviewers greatly improved the quality and clarity of the manuscript. I am indebted to J. Barthelme, C. Nelson and L. Robbins, whose foundational work made this study possible. Analysis and writing were supported by the National Science Foundation (grants BCS-1439123 and BCS-1124419), the National Geographic Society (grant 9473-14), Washington University in St Louis and the Turkana Basin Institute. Research in Kenya was carried out under NACOSTI permit \#14/4316/1875-A 2257.

\section{Supplementary material}

To view supplementary material for this article, please visit https:/doi.org/10.15184/aqy. 2019.178

\section{References}

Ambrose, S.H. 1984. The introduction of pastoral adaptations to the highlands of East Africa, in D. Clark \& S.A. Brandt (ed.) From hunters to farmers: the causes and consequences of food production in Africa: 212-39. Berkeley: University of California Press.

- 1998. Chronology of the later Stone Age and food production in East Africa. Journal of
Archaeological Science 25: 377-92.

https://doi.org/10.1006/jasc.1997.0277

- 2002. Small things remembered: origins of early microlithic industries in sub-Saharan Africa. Archeological Papers of the American Anthropological Association 12: 9-29.

- 2012. Obsidian dating and source exploitation studies in Africa, in I. Liritzis \& C. Stevenson (ed.) Obsidian and ancient manufactured glasses. Albuquerque: University of New Mexico Press. 
ANDrefsKy JR, W. 2009. The analysis of stone tool procurement, production, and maintenance. Journal of Archaeological Research 17: 65-103. https://doi.org/10.1007/s10814-008-9026-2

Ashley, G.M., E.K. Ndiema, J.Q.G. Spencer, J.W.K. Harris, P.W. Kiura, L. Dibble, A. Du \& P.T. Lordan. 2017. Paleoenvironmental reconstruction of Dongodien, Lake Turkana, Kenya and OSL dating of site occupation during Lake Holocene climate change. African Archaeological Review 34: 345-62. https://doi.org/10.1007/s10437-017-9260-4

Barthelme, J. 1977. Holocene sites north-east of Lake Turkana: a preliminary report. Azania: Journal of the British Institute in Eastern Africa 12: 33-41. https://doi.org/10.1080/00672707709511246

- 1981. Late Pleistocene-Holocene prehistory to the north-east of Lake Turkana, Kenya. Unpublished $\mathrm{PhD}$ dissertation, University of California, Berkeley.

- 1985. Fisher-hunters and Neolithic pastoralists in East Turkana, Kenya (Cambridge Monographs in African History 13, British Archaeological Reports International series 254). Oxford: Archaeopress.

Beyin, A. 2011. Recent archaeological survey and excavation around the greater Kalokol area, west side of Lake Turkana: preliminary findings. Nyame Akuma 75: 40-50.

Beyin, A., M.E. Prendergast, K.M. Grillo \& H. WANG. 2017. New radiocarbon dates for Terminal Pleistocene and Early Holocene settlements in west Turkana, northern Kenya. Quaternary Science Reviews 168: 208-15. https://doi.org/10.1016/j.quascirev.2017.04.012.

BINFORD, L.R. 1979. Organization and formation processes: looking at curated technologies. Journal of Anthropological Research 35: 255-73. https://doi.org/10.1086/jar.35.3.3629902

Bollig, M., M. Schnegg \& H.P. WotzKa (ed.). 2013. Pastoralism in Africa: past, present and future: 289-315. Oxford: Berghahn.

Bower, J. 1991. The pastoral Neolithic of East Africa. Journal of World Prehistory 5: 49-82. https://doi.org/10.1007/BF00974732

Bronk Ramsey, C. 2009. Bayesian analysis of radiocarbon dates. Radiocarbon 51: 337-60. https://doi.org/10.1017/S0033822200033865

Brown, F.H., B.P. Nash, D.P. Fernandez, H.V. Merrick \& R.J. Thomas. 2013.
Geochemical composition of source obsidians from Kenya. Journal of Archaeological Science 40: 3233-51. https://doi.org/10.1016/j.jas.2013.03.011

Cremaschi, M. \& S. di Lernia. 1999. Holocene climatic changes and cultural dynamics in the Libyan Sahara. African Archaeological Review 16: 211-38. https://doi.org/10.1023/A:1021609623737

GarceA, E.A.A. 2005. Comparing chaines opératoires: technological, cultural, and chronological features of pre-pastoral and pastoral ceramic and lithic productions, in A. Livingstone Smith, D. Bosquet \& R. Martineau (ed.) Pottery manufacturing processes: reconstitution and interpretation (British Archaeological Reports International series 1349): 215-28. Oxford: Archaeopress.

Gifford-Gonzalez, D. 2005. Pastoralism and its consequences, in A. Stahl (ed.) African archaeology: a critical introduction: 187-224. London: Blackwell.

Goldstein, S.T. 2018. Picking up the pieces: reconstructing lithic production strategies at a Late Holocene obsidian quarry in southern Kenya. Journal of Field Archaeology 43: 85-101. https://doi.org/10.1080/00934690.2018.1426958

-2019 . Knowledge transmission through the lens of lithic production: a case study from the pastoral Neolithic of southern Kenya. Journal of Archaeological Method and Theory 26: 679-713. https://doi.org/10.1007/s10816-018-9387-x

Grillo, K.M. \& E.A. Hildebrand. 2013. The context of early megalithic architecture in eastern Africa: the Turkana Basin c. 5000-4000 BP. Azania: Archaeological Research in Africa 48: 193-217. https://doi.org/10.1080/0067270X.2013. 789188

Hildebrand, E.A. \& K.M. Grillo. 2012. Early herders and monumental sites in eastern Africa: dating and interpretation. Antiquity 86: 338-52. https://doi.org/10.1017/S0003598X00062803

Hildebrand, E.A., J.J. Shea \& K.M. Grillo. 2011. Four Middle Holocene pillar sites in west Turkana, Kenya. Journal of Field Archaeology 36: 181-200.

https://doi.org/10.1179/ 009346911 X12991472411088

Hildebrand, E.A. et al. 2018. A monumental cemetery built by eastern Africa's earliest herders near Lake Turkana, Kenya. Proceedings of the

(C) Antiquity Publications Ltd, 2019 
National Academy of Sciences of the USA 115: 8942-47. https://doi.org/10.1073/pnas.1721975115

Holl, A.F. 2005. Holocene 'aquatic' adaptations in north tropical Africa, in A. Stahl (ed.) African archaeology: a critical introduction: 174-86. London: Blackwell.

Kuper, R. \& S. KRöPELIN. 2006. Climate-controlled Holocene occupation in the Sahara: motor of Africa's evolution. Science 313: 803-807. https://doi.org/10.1126/science.1130989

LAHR, M.M. et al. 2016. Inter-group violence among Early Holocene hunter-gatherers of West Turkana, Kenya. Nature 529: 394-98. https://doi.org/10.1038/nature16477

van der Lubbe, H.J.L., J. Krause-Nehring, A. Junginger, Y. Garcin, J.C.A. Joordens, G.R. Davies, C. Beck, C.S. Feibel, T.C. Johnson \& H.B. Vonhof. 2017. Gradual or abrupt? Changes in water source of Lake Turkana (Kenya) during the African Humid period inferred from Sr isotope ratios. Quaternary Science Reviews 174: 1-12. https://doi.org/10.1016/j.quascirev.2017.08.010

Marshall, F. \& E. Hildebrand. 2002. Cattle before crops: the beginnings of food production in Africa. Journal of World Prehistory 16: 99-143. https://doi.org/10.1023/A:1019954903395

Marshall, F., K. Stewart \& J. Barthelme. 1984. Early domestic stock at Dongodien in northern Kenya. Azania: Journal of the British Institute in Eastern Africa 19(1): 120-27. https://doi.org/10.1080/00672708409511332

Marshall, F., K.M. Grillo \& L. Arco. 2011. Prehistoric pastoralists and social responses to climatic risk in East Africa, in N. Miller, K. Moore \& K. Ryan (ed.) Sustainable lifeways: cultural persistence in an ever-changing environment: 39-74. Philadelphia: University of Pennsylvania Press.

McCABE, J.T. 2004. Cattle bring us to our enemies: Turkana ecology, politics, and raiding in a disequilibrium system. Detroit: University of Michigan Press.

https://doi.org/10.3998/mpub.23477

Nash, B.P., H.V. Merrick \& F.H. Brown. 2011. Obsidian types from Holocene sites around Lake Turkana, and other localities in northern Kenya. Journal of Archaeological Science 38: 1371-76.

https://doi.org/10.1016/j.jas.2011.02.001
Ndiema, E., C.D. Dillian \& D.R. Braun. 2010. Interaction and exchange across the transition to pastoralism, Lake Turkana, Kenya, in C.D. Dillian \& C.L. White (ed.) Trade and exchange: studies from history and prehistory: 95-110. New York: Springer. https://doi.org/10.1007/978-1-4419-1072-1_6

Nelson, C.M. 1973. A comparative analysis of later Stone Age occurrences in East Africa. Unpublished $\mathrm{PhD}$ dissertation, University of California at Berkeley.

- 1995. The work of the Koobi-Fora field school at the Jarigole pillar site. Kenya Past and Present 27: 49-63.

NeLson, N.C. 1991. The study of technological organization. Archaeological Method and Theory 3: 57-100.

Phillipson, D.W. 1977. Lowasera. Azania 12(1): $1-32$. https://doi.org/10.1080/00672707709511245

- 1984. Aspects of early food production in northern Kenya, in L. Krzyzaniak \& M. Kobusiewicz (ed.) Origin and early development of food-producing cultures in north-eastern Africa: 489-95. Poznan: Polish Academy of Sciences.

Prendergast, M.E. et al. 2019. Ancient DNA reveals a multistep spread of the first herders into sub-Saharan Africa. Science 30. https://doi.org/10.1126/science.aaw6275

Reimer, P.J. et al. 2013. IntCal13 and Marine13 radiocarbon age calibration curves $0-50000$ years cal BP. Radiocarbon 55: 1869-87. https://doi.org/10.2458/azu_js_rc.55.16947

Robbins, L.H. 1972. Archaeology in the Turkana District, Kenya. Science 176: 359-66. https://doi.org/10.1126/science.176.4033.359

- 1979. The Lothagam site: a Late Stone Age fishing settlement in the Lake Rudolph basin, Kenya (volume 1). Lansing: Michigan State University Press.

SADR, K. 2015. Livestock first reached southern Africa in two separate events. PLoS ONE 10: e0134215.

https://doi.org/10.1371/journal.pone.0134215

SawchuK, E.A., S.T. Goldstein, K.M. Grillo \& E.A. Hildebrand. 2018. Cemeteries on a moving frontier: mortuary practices and the spread of pastoralism from the Sahara into eastern Africa. Journal of Anthropological Archaeology 51: 187-205. https://doi.org/10.1016/j.jaa.2018.08.001 
SHackley, M.S. 1988. Sources of archaeological obsidian in the Southwest: an archaeological, petrological and geochemical study. American Antiquity 53: 752-72. https://doi.org/10.2307/281117

Sнотт, M. 1986. Technological organization and settlement mobility: an ethnographic examination. Journal of Anthropological Research 42: $15-51$. https://doi.org/10.1086/jar.42.1.3630378

Sutton, J.E. 1977. The African aqualithic. Antiquity 51: 25-34. https://doi.org/10.1017/S0003598X00100559

Tripcevich, N. \& D.A. Contreras. 2013. Archaeological approaches to obsidian quarries: investigations at the Quispisisa source, in N. Tripcevich \& K.J. Vaughn (ed.) Mining and quarrying in the ancient Andes: 23-44. New York: Springer. https://doi.org/10.1007/978-1-4614-5200-3_2

Wallace, I.J. \& J.J. Shea. 2006. Mobility patterns and core technologies in the Middle Paleolithic of the Levant. Journal of Archaeological Science 33: 1293-309. https://doi.org/10.1016/j.jas.2006.01.005

Wandibba, S. 1977. An attribute analysis of the ceramics of the early pastoralist period from the southern Rift Valley, Kenya. Unpublished MA dissertation, University of Nairobi.

Wright, D.K. \& S.L. Forman. 2011. Holocene occupation of the Mount Porr Strand Plain in southern Lake Turkana, Kenya. Nyame Akuma 76: 47-62

Wright, D.K., S.L. Forman, P. Kiura, C. Bloszies \& A. Beyin. 2015. Lakeside view: sociocultural responses to changing water levels of Lake Turkana, Kenya. African Archaeological Review 32: 335-67. https://doi.org/10.1007/s10437-015-9185-8

Wright, D.K., K.M. Grillo \& R. Soper. 2016. Stone cairns and material culture of the Middle to Late Holocene, Lake Turkana. Journal of African Archaeology 14: 209-22.

https://doi.org/10.3213/2191-5784-10287

Received: 23 January 2019; Revised: 4 March 2019; Accepted: 11 March 2019

(C) Antiquity Publications Ltd, 2019 